\title{
Land Suitability Analysis for Policy Making Assistance: A GIS Based Land Suitability Comparison between Surface and Drip Irrigation Systems
}

\author{
A. H. Rabia, H. Figueredo, T. L. Huong, B. A. A. Lopez, H. W. Solomon, and V. Alessandro
}

\begin{abstract}
Land suitability assessment for irrigation is a very important tool not only in terms of agriculture development planning, but also to overcome the global problem of water scarcity. The aim of this study is to spatially evaluate land suitability of the study area, Kilte Awulaelo district in Ethiopia, for surface and drip irrigation methods based on GIS and remote sensing approaches. This work has been done as a part of the $29^{\text {th }}$ Course Professional Master in Istituto Agronomico per l'Oltremare, Florence, Italy. Final suitability maps show the irregularity of suitability classes' distribution over the study area. Results show that only $15 \%$ of the study area is suitable for surface irrigation. This is due to the limitation of the topography and stoniness factors for surface irrigation suitability. GIS and remote sensing was highly efficient for modeling and developing land suitability maps together with spatially compare land suitability for deferent irrigation methods.
\end{abstract}

Index Terms-Ethiopia, GIS and remote sensing, irrigation systems, land suitability, spatial modeling.

\section{INTRODUCTION}

Good management of natural resources of the most important determinants that leads to balanced food security in the world. Any imbalance in one of these resources, by extension, leads to an imbalance in the ecosystem and thus the disparity in the global food security. As a result of global problems like water scarcity, continued population growth and the agriculture soil sealing, the area of agricultural land is decreasing continuously and often the most suitable land in terms of agriculture is lost [1]. This led to the decrease in agricultural production from irrigated lands to $40 \%$ of food requests [2].

Manuscript received October 23, 2012; revised January 7, 2013. This work was supported in part by Istituto Agronomico per l'Oltremare (IAO), Florence, Italy.

A H. Rabia is with University of Naples "Federico II", Faculty of Agriculture, Department of Science of Soil, Plant, Environment and Animal Production. Via Università $100-80055$ - Portici- Napoli, Italy (e-mail: operaharb@hotmail.com).

H. Figueredo is with Ministry of Development Planning, Vice-Ministry of Planning and Coordination, General Direction of Territorial Planning - La Paz, Bolivia.

T. L. Huong is with Asian Management and Development Institute, Hanoi, Vietnam.

B. A. A. Lopez is with San Carlos University, Faculty of Agronomy, Guatemala.

H. W. Solomon is with Haramaya University, College of Agriculture and Environmental Sciences, School of Natural Resources Management and Environmental Sciences, Dire Dawa, Ethiopia.

V. Alessandro is with Istituto Agronomico per l'Oltremare, Via A. Cocchi 4 Firenze, Italy.
"Land suitability is the appropriateness of this land for a defined use. The land may be considered in its present condition or after improvements. The process of land suitability classification is the appraisal and grouping of specific areas of land in terms of their suitability for defined uses [3]. This kind of test "land suitability analysis" is an essential starting point for the development. Where, it provides the necessary information about the deferent limitations and the possible opportunities for the land use under investigation based on the land capabilities. Ethiopia's economy is mainly depending on agricultural sector but there is shortage of rainfall especially in the northern part of the country. In Tigray, north east of Ethiopia, irrigation is considered as necessary to support the agricultural base as it plays a very important role in improving the livelihood of farmers. The effective and sustainable utilization of the limited water resource is very crucial in arid and semi-arid areas like Tigray. According to [4], in 1995 the regional government of Tigray initiated an ambitious plan to construct 500 dams within ten years with a capacity of irrigating 50,000 ha in the moisture stressed and drought prone areas. A mandate commission has been established to increase crop production through construction of micro-dams and irrigation infrastructure under Sustainable Agriculture and Environmental Rehabilitation of Tigray [5], [6]. The plan, however, had to be scaled back because of lack of suitable sites for dam construction and resource constraints. By the end of 1997, 25 dams with a nominal capacity of irrigating $2,500 \mathrm{ha}$ of land were completed. But most of the completed dams are operating much below their capacity due to a shortage of water. Only about $300 \mathrm{ha}$ of land were actually being irrigated in 1998.

In Kilte Awulaelo Woreda "district", one of Tigray's districts, farmers are becoming increasingly aware of irrigation as a tool for optimizing production. When all other management practices are carried out efficiently, irrigation can help the farmers achieve the top yields and quality demanded for self food security and even for marketing. In the study area irrigation is practiced from many water sources: surface water like streams, water harvesting and digging wells from the ground water. During the field work a good observation was that there is a soil and water conservation practices on the hill sides that enhance the increment of water table level at the foot slope field, encouraging farmers to dig a well for irrigation practice [7], [8]. The quantity of water needed for irrigation is significant and different crops have different water needs, and each irrigation system should be designed to provide adequate water for the crop to be 
irrigated.

According to [9], in Kilte Awulaelo Woreda $71.5 \%$ of the population lives in rural areas, and agricultural cover is estimated to be 72.145 ha over an area of 1013.5 square kilometers. The agricultural coverage represents $31.38 \%$ of the total land, while $39.71 \%$ defined as "agricultural and degradation control", which is mixed agriculture and scrubs. With respect to the total agricultural area the rainfed annual crop surface occupies $84 \%$, the mixed rainfed-irrigated $13.4 \%$ and the irrigated fields represent only the $2.6 \%$. Studies have investigated the land suitability for agriculture activities in the study area for different agriculture crops, but didn't take into account the land suitability for deferent irrigation methods [10]. Due to the national policy of land redistribution, the land holding size is less than one hectare per family. Farmers usually work on two (or more) small plots of land, one with the irrigation facilities and one on the rainfed base. They apply traditional methods of cultivation, but hand hoe is not a common cultural practice. Oxen are used for ploughing, and some farmers consider rent their oxen in change of crops. All the family is usually involved in the agricultural activities, men are responsible of ploughing and for the land preparation; during the harvesting period also women and children are engaged in working in the field.

The rainfed agricultural production is strongly dependent on the duration and variability of the rainfalls. The main rain season goes from July to August, but for the short cycle crop rotation the entity and duration of the "Belg" (short raining season) from December to March is very important. Wheat, barley, maize and teff are the principal cereals cultivated. The crop rotation is quite practiced in the district, and in order to increase the crop yields, farmers are used to add natural compost, but more frequently chemical fertilizers are added like urea and Diammonium Phosphate (DAP). The agriculture supports the domestic consumption and the exceeded are sold in the local markets. The rainfed annual agriculture requires most of the time terraced and artificial soil conservation and drainage interventions like ditches and particular ploughing practices.

In the study area, the surface irrigation is mainly practiced in the fluvial valley and near the important rivers or dams where a system of channels was built implementing the streams diversion. Irrigation is also related to the ponds and wells distribution. The irrigated fields are sparse small plots, fragmented all over the district in lowest or flat zones. In most of the cases artificial terraces are constructed to maximize water retention. The irrigation is used to cultivate tomato, pepper, potato, onion, cabbage and maize. The production of the vegetables is first of all for the family self subsistence. But sometimes crops are planted according to the market demand. The irrigation use coincides with the summer time, starting in October, and then it is suspended during the rainy season.

The main objective of this study is to spatially evaluate the land suitability of the study area for surface and drip irrigation based on GIS and remote sensing approaches in order to help policy makers to develop a sustainability management plan for the agricultural land. This publication is a part of a study for natural resources evaluation in the study area. This last study was titled as Land Evaluation in
Kilte Awulaelo District - Tigray Region, Ethiopia and it was the result of the students' work in 29th Course Professional Master "Geomatics and Natural Resources Evaluation", held at the Istituto Agronomico per l'Oltremare, Florence, from November 2008 to June 2009. Florence, Italy [11].

\section{Materials AND MethodS}

\section{A. Study Area}

Kilte Awulaelo District is situated in the eastern part of Tigray region, one of the nine Regional States of Ethiopia. Located in the north-eastern part of the country, Kilte Awulaelo Woreda is subdivided into seventeen Tabia (parishes) and it is located between $13^{\circ} 33^{\prime}$ and $13^{\circ} 58^{\prime}$ North latitude and $39^{\circ} 18^{\prime}$ to $39^{\circ} 41^{\prime}$ East longitude (Fig. 1). The elevation range of the area goes from 1760 to $2720 \mathrm{~m}$. The estimated total population accounts for 121,260 inhabitants, which represent the $12 \%$ of the country. The urban population is around the $28.56 \%$ of the total, over an area of $987.83 \mathrm{~km}^{2}[12]$.

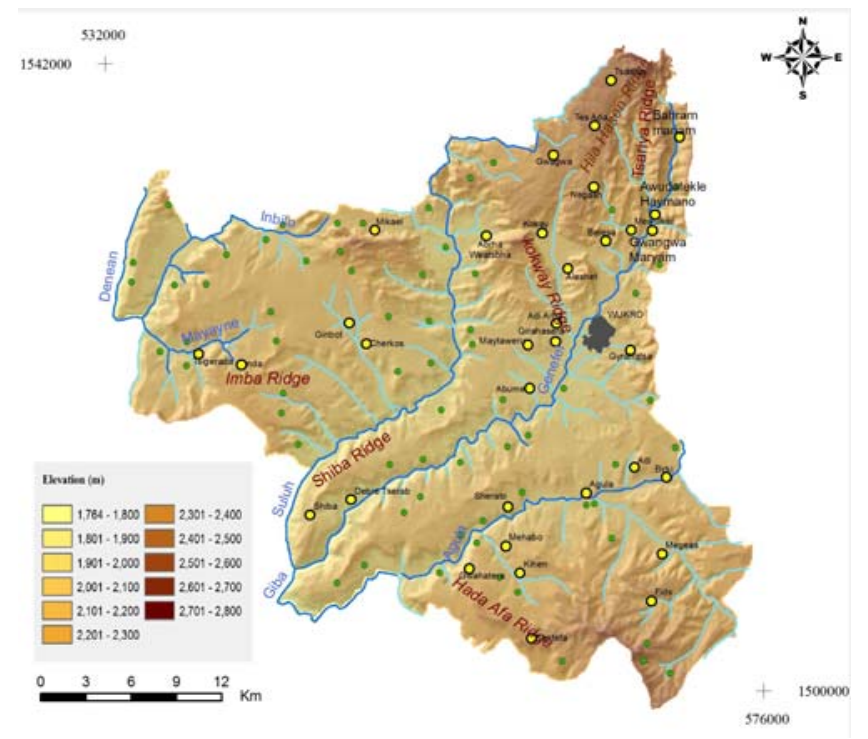

Fig. 1. Sketch of the study area.

The lithology of the study area is represented by a succession of geological formations from Precambrian to Quaternary age. The basement, corresponding to the Precambrian rocks [13], is made up by two major sequences: An older (Lower Proterozoic) predominantly metavolcanic green schist with marble and quartzite (Tsaliet Formation), and a younger (Precambrian) metasedimentary pebbly slate and black limestone (Tambien Formation). The lithological succession of the Paleozoic consists of quartz diorite (Forstaga Formation) and pink to gray granite and granodiorite (Mareb Formation), which represent the lower Paleozoic. The Ordovician glacial sediments [14] are represented by colluvial deposit on glacial dark tillite (Adaga Formation) and glacial white quartz sandstone (Enticho Formation). Enticho sandstone is exposed to the east and north of the glacigenic deposits and seems to have been deposited in a different basin than the glacial sediments [15]. The Mesozoic sedimentary sequence outcrops over $80 \%$ of the study area and it is composed mainly by formations that 
from bottom to top are called: Adigrat Sandstone, Antalo Limestone and Agula Shale. The lithology of these formations is well described [16]. The Tertiary volcanism is represented by Mekele Dolerite Formation and the Quaternary formations are formed by from lacustrine, alluvial and colluvial deposits.

Agriculture is the most important source of subsistence for the majority of the population. The study area presents different topographies and geomorphologies with different agro ecological conditions. Two main agro-climatic zones are found: Weyna Dega and Dega, influencing the land-cover and land use of the Woreda. The Weyna Dega is a cool sub-humid altitudinal climatic zone. The altitudes vary between $1500-2500 \mathrm{~m}$. The annual rainfalls are in the range of $800 \mathrm{~mm}$ to $1200 \mathrm{~mm}$. This climatic condition is favorable for wheat, maize, teff and pulses cultivation. The Dega, cool humid highland zone is characterized by altitudes higher than $2500 \mathrm{~m}$, and the presence of crops plantation such as barley and wheat. The average temperature in Kilte Awulaelo District is between $16^{\circ} \mathrm{C}$ and $34^{\circ} \mathrm{C}$ and the annual average rainfall is within the range of $500 \mathrm{~mm}$ to $1200 \mathrm{~mm}$.

The mean annual soil sediment accumulation with the stone bunds is estimated in $119 \mathrm{~kg}$ ha-1 per year and in percentage, the annual soil loss reduction due to the water erosion is about $68 \%$ [17]. Another report has been published by [18] propose that dramatic increases in land degradation and soil erosion rates happened as a result of population increases during the latest 50 to 100 years.

\section{B. Land Suitability Analysis}

The FAO approach defines Land Suitability as aptitude of a given type of land to support a defined use [3]. The basic idea underlying the proposed method of land suitability classification is that the land should be rated only on its value for a specific purpose [19]. According to the classification proposed by [20], five different classes, ranging from "Unsuitable" to "Highly suitable", whose codes are constituted by a capital letter (indicating the order) and a number (indicating the class); identify the land suitability for a certain purpose (Table I).

TABLE I: SUITABILITY INDICES FOR THE DIFFERENT SUITABILITY CLASSES.

\begin{tabular}{|c|c|c|}
\hline $\begin{array}{l}\text { Suitability } \\
\text { Class }\end{array}$ & $\begin{array}{l}\text { Suitability } \\
\text { index (SI) }\end{array}$ & Description \\
\hline $\begin{array}{l}\text { Class S1: } \\
\text { Highly } \\
\text { suitable }\end{array}$ & $>80$ & $\begin{array}{l}\text { Land having no limitations for a given use, } \\
\text { or limitations that do not reduce appreciably } \\
\text { the productivity and benefits, with no need } \\
\text { for a high level of input }\end{array}$ \\
\hline $\begin{array}{l}\text { Class S2: } \\
\text { Moderately } \\
\text { suitable }\end{array}$ & $60-80$ & $\begin{array}{l}\text { Land having minor limitations that could } \\
\text { reduce productivity or benefits, additive } \\
\text { inputs are required to reach the same yield } \\
\text { as that of class } \mathrm{S} 1\end{array}$ \\
\hline $\begin{array}{l}\text { Class S3: } \\
\text { Marginally } \\
\text { suitable }\end{array}$ & $45-59$ & $\begin{array}{l}\text { Land having moderate limitations for a } \\
\text { certain use, in which the amount of surplus } \\
\text { input is only marginally justified }\end{array}$ \\
\hline $\begin{array}{l}\text { Class N1: } \\
\text { Currently } \\
\text { unsuitable }\end{array}$ & $30-44$ & $\begin{array}{l}\text { Land with severe limitations for the land } \\
\text { use under consideration. Every sustainable } \\
\text { use is precluded at the present time and the } \\
\text { costs for correction are unacceptable with } \\
\text { the existing condition. Only new } \\
\text { technologies could improve land } \\
\text { productivity }\end{array}$ \\
\hline $\begin{array}{l}\text { Class N2: } \\
\text { Permanently } \\
\text { unsuitable }\end{array}$ & $<30$ & $\begin{array}{l}\text { Land use type under analysis is not } \\
\text { acceptable at all for the land }\end{array}$ \\
\hline
\end{tabular}

The process of land suitability evaluation using this method is appraisal and grouping of specific Land Unit in terms of their suitability for defined use. According to the percentage of different facets in each unit, if the dominant suitability class does not represent at least $60 \%$ of the Land Unit, a mixed class is created. There are two kinds of conditions:

If two adjacent classes constitute together more than $60 \%$ of the Land Unit, the expression "mixed classes" is applied: for example, S1S2 means "Highly Suitable to Moderately Suitable";

If the classes are not adjacent, the "mixed class" is described with a slash symbol '/' between the two codes: for example, S1/S3 meaning "Highly Suitable and Marginally Suitable";

The Symbol "NR", which means "Not Relevant", is used to describe areas excluded from the suitability evaluation (i.e.: urban areas, villages, military camps and water bodies).

According to the availability of data, the methodology has been based on [21] parametric approach to evaluate land suitability for irrigation taking into account soil proprieties (physically and chemically) and the topography (slopes) of the study area. Chemical and physical soil proprieties have been determined in the soil laboratory using routine analysis processing. The texture classification is based on the USDA triangle. The land suitability was carried out for each Land Unit previously identified following the IAO approach [22], [23]. In particular the objective of this holist method is to produce a Land Unit map containing all data, the land unit is a homogeneous land portion, regarding to the natural recourses such as geology, geomorphology, soils, land cover, land use and agriculture.

The calculation of a suitability index for irrigation considers some factors influencing the soil such as:

Slope: Estimated considering the difference between terraced and non-terraced slopes;

Surface stoniness: Rated with regard to the rock fragment coverage.

Drainage: A limiting factor when it is imperfect or weak. The rating for drainage is related to texture;

Texture: Rated taking into account the permeability and available water content and calculated as weighted average for the upper $100 \mathrm{~cm}$;

Soil depth: Rated with regard to the thickness and the characteristic of the soil layers (horizons);

Calcium carbonate status: Influencing the relationship between soil and water, and the availability of nutrient supply for plant. It is rated with regard to the $\mathrm{CaCO} 3$ content effect on soil profile;

Salinity or alkalinity: Rated on the base of the exchangeable sodium percentage and electric conductivity;

From texture and control section used the lower limits of each horizons, an average texture ( $\%$ of silt, clay and sand) is computed for each profile, with the given depth of the control section. After that it carries out all calculations needed to average parameters along the control section. Each horizon (and its corresponding parameters' values) is averaged according to its effective contribution (in $\mathrm{cm}$ ) to the control section. Finally evaluation data where used for quality control and producing rating and suitability classes (Fig. 2). 


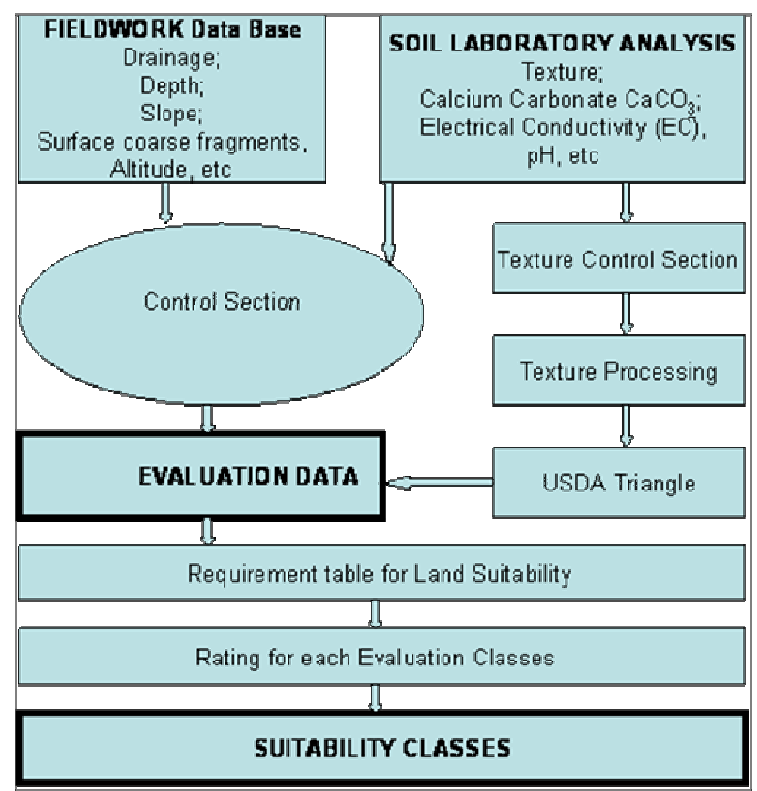

Fig. 2. Flow chart of Land Suitability analysis.

Taking into account the aforementioned seven parameters, rates have been assigned to each factor affecting the suitability for irrigation. Thus, a suitability index for irrigation (Si) has been developed as shown in (1) below:

$$
\text { Si }=A \times \frac{B}{100} \times \frac{C}{100} \times \frac{D}{100} \times \frac{E}{100} \times \frac{F}{100} \times \frac{G}{100}
$$

where:

Si: suitability index for irrigation;

$A$ : rating of soil texture;

$B$ : rating of soil depth;

$C$ : rating of $\mathrm{CaCO} 3$ status;

$D$ : salinity/alkalinity rating;

$E$ : drainage rating;

$F$ : slope rating

$G$ : rating of surface stoniness

\section{RESUlTS AND DISCUSSION}

If In the study area, dominantly surface irrigation is practiced in many parts. According to the [9], in the study area 1,208 hectares of land is utilized to irrigate for vegetable production and 348 hectares of land for cereal crops. In the report it is explained that 326,182 quintals of variety of vegetable and 9,608 quintals of cereals were grown using irrigation. For each land site "relevé" a suitability class has been assigned and it has been generalized for the overall Land Units to generate a thematic layer. Initially, the first and mixed suitability classes have been generated following the model (Fig. 2). Taking in to account the heterogeneity for the physical and chemical parameters of the study area, the mixed class is preferred to use for the suitability index in both the surface and drip irrigation, as shown in Fig. 3 and 4. Usage of mixed class extends more classes of suitability than assigning very limited number with one single class. Most of the rugged topography from undulating rise to steep scarp has been classified either currently unsuitable or permanently unsuitable for surface and drip irrigation. Reference [24] explained that topography is a major factor affecting irrigation, particularly surface irrigation. The main limiting factor in using surface and drip irrigation methods in the study area is also slope. Slope and changes in slope of the irrigated area have a major influence over selection of method of irrigation, which requires modification of the escarped landform [25]. To overcome this, the dissected steep hills in the Negash synclinorium, steep and sloping slopes in the Mekele plateau, and the steep scarp of the Antalo Formation land system have not been considered suitable to any of the aforementioned two irrigation systems. Knowing that, modifying the slope gradient artificially requires huge investments that would be above the economical capacity of the Woreda capital resources.

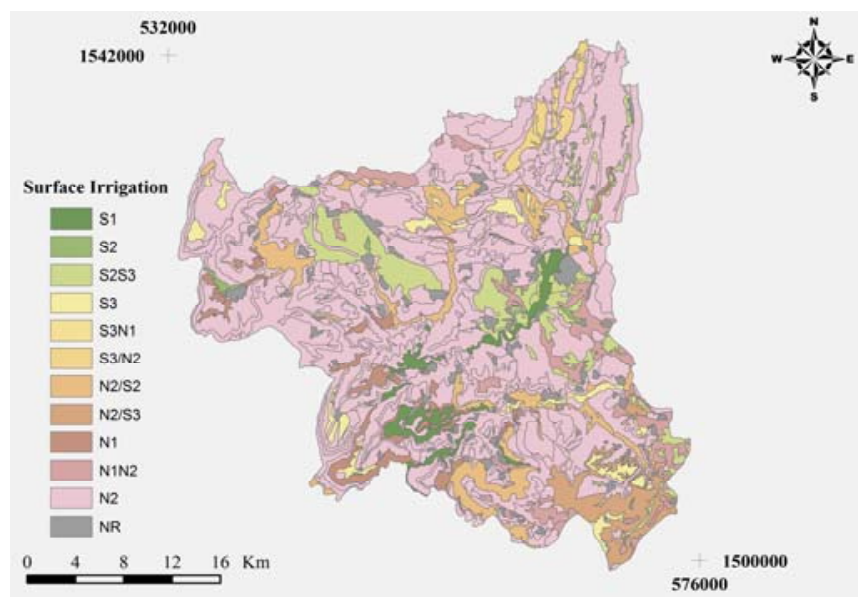

Fig. 3. Land suitability map for surface irrigation.

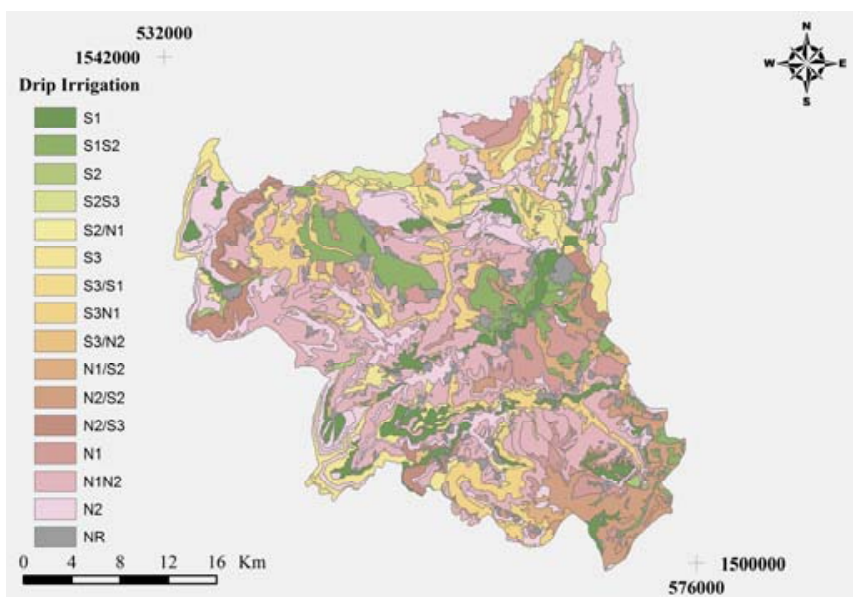

Fig. 4. Land suitability map for drip irrigation.

\section{A. Surface Irrigation}

According to [24], surface irrigation has evolved into an extensive array of configurations which can be broadly classified as: (1) basin irrigation, (2) border irrigation, (3) furrow irrigation, and (4) uncontrolled flooding.

In Kilte Awulaelo Woreda, areas with colluvial and alluvial deposits, which account about $3 \%$, have been found to be highly suitable (S1) for surface irrigation (Table 2). Currently, the alluvial deposit found along the Giba River tributaries of the level plains is also used for rainfed agriculture. Moreover, some Land Units classified as moderately suitable (S2) $0.2 \%$, and slightly suitable (S3), for about $3 \%$ of the study area, are located along the Giba River tributaries of the alluvial deposit. About $2 \%$ of the study area is classified as mixed classes of moderately suitable to 
marginally suitable (S2S3). Large part of the study area (63\%) is classified as permanently unsuitable (N2) for surface irrigation by any means (Fig. 3). All the land system with the landforms of undulating rise, steep scarp, dissected slope, steep hills and ridges are underlying with the permanently unsuitable class [26]. The major parameters which affect for this condition are the topography, surface stoniness of the land, and depth of the soil [27]. In many parts of the study area, farmers has already recently introduced surface irrigation by collecting water from a hand dug well as well as streams and pumping using generators to the surface to produce perennial and annual crops.

\section{B. Drip Irrigation}

Drip irrigation is helpful for the slow application of low pressure water to soil and plants using plastic tubes placed directly at the plants root zone. Drip irrigation can help farmers to use water efficiently. A well-designed drip irrigation system practically avoids water runoff, deep percolation, or evaporation [28].

According to [29], it is described that drip irrigation has many advantages over other irrigation methods:

Water is discharged uniformly along the lateral (pipe fitted with drippers) even on moderately sloping terrain. The invention of compensated drippers enables uniform irrigation of steeper slopes and long distances. Efficient irrigation directs water to a plant's active root system with maximum efficiency, and the best and newest method is drip irrigation.

Water losses as a result of evaporation from soil surface, surface runoff, or deep percolation, are minimal because of applying it at slow rates and to limited areas.

Drip irrigation generally achieves higher and better quality crop yields, soil moisture in the active root zone continuously at an optimum level, introduces fertilizers effectively into the root zone with the irrigation water. Drip irrigation is more suitable for crops and vegetables planted in rows for areas adaptable to any farmable slopes. It is recommended to utilize drip irrigation for high value crops as it demands high capital costs of installing a drip system [28].

As Table 3 indicates, considering the mixed classes in the study area, drip irrigation (Fig. 4) accounts $5 \%$ as highly suitable (S1), $1 \%$ moderately suitable (S2), and $6 \%$ as marginally suitable (S3). Similarly, large part of the study area $(23 \%)$ is classified as permanently unsuitable (N2) and significant amount $(6 \%)$ as currently unsuitable (N1). Moreover, a paramount proportion (22\%) of the area is also classified as currently unsuitable to permanently unsuitable (N1N2) for drip irrigation [30].

Fig. 5 shows a comparison of land suitability percentages of the two irrigation methods considering only the main classes without any mixing. In all suitability cases, the comparison of the two types of irrigation techniques revealed that the drip irrigation suggested as more effective and efficient than the surface irrigation methods for improving the suitability to the irrigation purposes [31]. As the study area is composed of heterogeneous physiographic features, from undulating to steep scarp, the drip irrigation suitability gave more irrigable areas of $28 \%$ of the study area $(\mathrm{S} 1=6 \%$, $\mathrm{S} 2=9 \%, \mathrm{~S} 3=13 \%$ ) compared to the surface irrigation practice of $15 \%(\mathrm{~S} 1=3 \%, \mathrm{~S} 2=1 \%, \mathrm{~S} 3=11 \%)$ [31]. This is mainly due to the topographic (slope), soil properties (depth and texture), surface stoniness and drainage limitations worked out in the surface irrigation suitability evaluation [32].

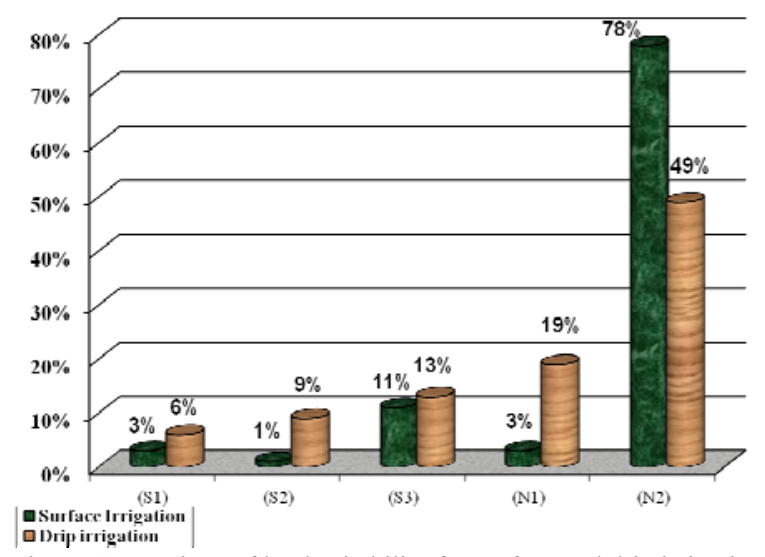

Fig. 5. Comparison of land suitability for surface and drip irrigation

It is true that in areas like Tigray region, with long dry season period, is recommended to utilize drip irrigation as loss of water slightly happens, since water surface flow and outflow to the depth are both prevented. Moreover, drip irrigation system prevents the loss of ground and soil erosion, and provides equally watering possibilities, which never adversely affected by wind, rugged ground or thermal fluctuations like traditional ones. The major constraint of using drip irrigation system is the installation cost, higher than surface irrigation, but it is assumed that long run benefit considerations are taking into account. Governmental projects should encourage the installation of drip irrigation system because of its influence on increasing the water use efficiency as well as crop yields. This calls for governmental support to farmers to help in the first construction of drip irrigation system and to increase farmers' awareness of the benefits of using it.

\section{CONCLUSION}

Land suitability assessment for irrigation is a very important tool not only in term of agriculture development planning, but also to overcome the global problem of water scarcity. Choosing the suitable irrigation method is even more important for developing the irrigation plan on regional and national scale. Based on the results of this study, it was clear the diversity in suitability classes for both surface and drip irrigation methods, and also the patchy spatial distribution of the deferent suitability classes. Topography and surface stoniness were the major factors reducing land suitability for surface irrigation system, while they had much less influence on land suitability for drip irrigation system. Comparing land suitability of the study area for deferent irrigation method showed that the area of suitable land for drip irrigation is nearly double the area suitable for surface irrigation. This can be explained for the easiness of drip irrigation method application and also the low influence of many of the suitability limiting factors. The study recommended that drip irrigation is a better choice than surface irrigation in rugged topography areas according to the comparison of land suitability between the two irrigation 
methods. GIS and remote sensing was highly efficient for modeling and developing land suitability maps together with spatially compare land suitability for deferent irrigation methods.

\section{ACKNOWLEDGMENT}

The Authors would like to extend their gratitude to Dr. Luca Ongaro who, indeed, provided all forms of scientific supports and also to Stefano Berti and Ivano Tamantini for soil laboratory analysis.

\section{REFERENCES}

[1] A. H. Rabia, "Modeling of Soil Sealing by Urban Sprawl in Wukro, Ethiopia Using Remote Sensing and GIS Techniques," Taza GIS-Days: the International conference of GIS Users, Fez, Morocco, Sidi Mohamed Ben Abdellah University, May 23-24, 2012, pp. 484-488.

[2] G. H. Hargreaves and G. P. Merkley, Irrigation Fundamentals. Water Resources Publications, Englewood, CO, pp. 182.

[3] FAO, "A framework for land evaluation," Soils Bulletin 32. FAO, Roma. Pp. 72, 1976.

[4] H. Fitsum, J. Pender, and N. Gebreselassie, "Land degradation in the Highlands of Tigray and Strategies for Sustainable Land Management," Socioeconomic and Policy Research Working Paper 25, Addis Ababa Ethiopia, pp. 73, 1999.

[5] SAERT, Sustainable agricultural and environmental rehabilitation in Tigray: statistical master-book of Tigray, vol. XIII, UNDP, ECA, TDA and the Regional Government of Tigray, pp. 239, 1994.

[6] K. Esser, T. Vågen, Y. Tilahun, and M. Haile. Soil conservation in Tigray, Ethiopia. Esser, Kjell, Noragric Report No.5. Noragric. Centre for International Environment and Development Studies Agricultural University of Norway (NLH). [Online]. Available: http://www.umb.no/statisk/noragric/publications/reports/2002_nor_re p 5 bodytxt.pdf

[7] A. H. Rabia, "GIS Spatial Modeling for Land Degradation Assessment in Tigray, Ethiopia," $8^{\text {th }}$ International Soil Science Congress on "Land Degradation and Challenges in Sustainable Soil Management", Çeşme -Izmir, Turkey, Ege University, May 15-17, 2012, vol. 3, pp. 161-167.

[8] A. H. Rabia, "Mapping Soil Erosion Risk Using Rusle, GIS and Remote Sensing," The $4^{\text {th }}$ International Congress of ECSSS, EUROSOIL 2012 "soil science for the benefit of mankind and environment”, Bari, Italy, pp. 1082, 2012.

[9] Central Statistical Agency (CSA). [Online]. Available: www.csa.gov.et.

[10] A. H. Rabia, "A GIS based Land Suitability Assessment For Agricultural Planning In Kilte Awulaelo District, Ethiopia," The $4^{\text {th }}$ International Congress of ECSSS, EUROSOIL 2012 "soil science for the benefit of mankind and environment”, Bari, Italy. pp. 1257, 2012.

[11] IAO, "Land Evaluation in Kilte Awulaelo District - Tigray Region, Ethiopia," 29th Course Professional Master "Geomatics and Natural resources evaluation," Istituto Agronomico per l'Oltremare, pp. 231, 2009.

[12] Federal Democratic Republic of Ethiopia population census commission (FDR), "Summary and statistical report of the 2007 population census commission," Addis Ababa. pp. 133, 2008.

[13] Beythm, "Paleozoic-Mesozoic Sedimentary Basin of Mekele Outlier, Northern Ethiopia," The American Association of Petroleum Geologists Bulletin vol, 56, pp. 2426-2439. 1972.

[14] D. Girmay, "Geological characteristic and economic evaluation of oil shale deposits in Tigray, Ethiopia," Tigray Region Bureau of Water Resource, Mines and Energy, Ethiopia and Mekele University, Department of Applied Geology. 29th Oil Shale Symposium Colorado School of Mines, pp. 8, 2006.

[15] R. Bussert and E. Schrank, "Palynological evidence for a latest Carboniferous-Early Permian glaciation in Northern Ethiopia," Journal of African Earth Sciences, vol. 49: pp. 201-210, 2007.

[16] A. Bosellini, A. Russo, P. L. Fantozzi, G. Assefa, and T. Solomon, "The Mesozoic succession of the Mekele outlier (Tigre province, Ethiopia)," Memorie di Scienze Geologiche, Padova, vol. 49, pp. 95-116, 1997.

[17] G. Desta, J. Nyssen, J. Poessen, J. Deckers, H. Mitiku, G. Govers, and J. Moeyersons, "Effectiveness of stone bonds in controlling erosion on cropland in Tigray Highlands, northern Ethiopia," Soil Use and Management, vol. 21, pp. 287-297. 2005.

[18] NEDECO, Tekze River Basin Mater Plan Integrated Project, Land Degradation and Soil Conservation (ENV1), Amersfoort, Netherlands. 1997.

[19] I. Sys, E. Van Ranst, and J. Debaveye, Land evaluation, part I. Principles in land evaluation and crop production calculations, General administration for development cooperation, Brussels, pp. 40, 1991.

[20] FAO, Approaches to land classification, Soils Bulletin 22. FAO, Rome. pp. 120,1974

[21] I. Sys, E. Van Ranst, and J. Debaveye, Land evaluation, part II. Methods in land evaluation, General administration for development cooperation, Brussels, pp. 247, 1991.

[22] L. Ongaro, "Land unit mapping for land evaluation," Relazioni e monografie agrarie, nuova serie $\mathrm{n}^{\circ} 115$, Istituto Agronomico per l'Oltremare, pp. 52, Florence. 1998.

[23] L. Ongaro, "Land unit mapping for land evaluation (revised), Handout of the Master's degree "Geomatics and Natural Resources Evaluation," Istituto Agronomico per l'Oltremare, pp. 30, Florence. 2011.

[24] W. Walker, Guidelines for designing and evaluating surface irrigation, FAO Irrigation and Drainage Paper No. 45. FAO, Rome.

[25] A. Landi, S. Boroomand-Nasab, M. Behzad, M. R. Tondrow, M. Albaji, and A. Jazaieri, "Land Suitability Evaluation for Surface, Sprinkle and Drip Irrigation Methods in Fakkeh Plain, Iran," Journal of Applied Sciences vol. 8, pp. 3646-3653. 2008.

[26] M. Jovzi, M. Albaji, and A. Gharibzadeh, "Investigating the Suitability of Lands for Surface and Under-Pressure (Drip and Sprinkler) Irrigation in Miheh Plain," Research Journal of Environmental Sciences vol. pp. 51-61. 2012.

[27] Y. Briza. Land suitability for irrigation. In "Land evaluation in the province of Ben Slimane, Morocco," 21st Course professional Master "Remote sensing and Natural Resources Evaluation," Istituto Agronomico per l'Oltremare. (2001). Florence. pp. 64-67. [Online]. Available:http://www.iao.florence.it/training/geomatics/Report.php

[28] A. Kirkpatrick, L. Browning, J. W. Bauder, R. Waskom, M. Neibauer, and G. Cardon, Irrigating with Limited Water Supplies: A Practical Guide to Choosing Crops Well-Suited to Limited Irrigation. Montana State University, Extension Service. pp 29, 2006.

[29] D. Sitton. Advanced agriculture as a tool against desertification. Applied Research Institutes, Ben-Gurion University of the Negev. 2000. [Online]. Available: http://goo.gl/zSSOq

[30] M. Albaji, A. Landi, S. Boroomand-Nasab, and K. Moravej, "Land suitability evaluation for surface and drip irrigation in shavoor plain Iran," Journal of Applied Science vol. 8, pp. 654-659. 2008.

[31] O. Dengiz, "A comparison of deferent irrigation methods based on the parametric evaluation approach," Turkish Journal of Agriculture and Forestry, vol. 30, pp. 21-29, 2006.

[32] T. F. Scherer, B. Seelig, and D. Franzen. Soil, water and plant characteristics important to irrigation. EB-66. February 1996. North Dakota. USDA. 1996. [Online]. Available: http://www.ag.ndsu.edu/pubs/ageng/irrigate/eb66w.htm

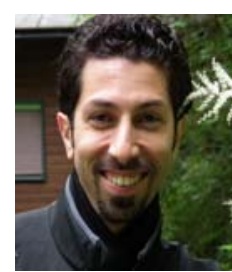

A. H. Rabia is an assistant lecturer at Faculty of Agriculture, University of Damanhur, Egypt. He holds a Master's Degree Course in Geomatics and Natural Resources Evaluation from Faculty of Agriculture, Firenze University, Italy, a Master's degree in Soil and Water science from Alexandria University (2007) and Bachelor of Science from Faculty of Agriculture, Alexandria University (2001). $\mathrm{He}$ is currently a PhD scholar at university of Naples "Federico II", Italy. His $\mathrm{PhD}$ is about improvement and management of agricultural resources and forests.

His main fields of scientific interests include soil science, GIS and remote sensing, Impacts of Climate change on soils, land use change and climate change modeling.

Dr. Rabia is a member of many professional societies as the Italian Society for Soil Science SISS, the International Geospatial Society, the Global Spatial Data Infrastructure Association, the Egyptian Society for Soil Sciences, Prof. Dr. A. M. Balba Society for Soil and Water Research, Journal of Agricultural and Environmental Sciences, Alexandria Science Exchange Journal. 